\title{
The Roles of Earthworms in Agroecosystem
}

\author{
Agus Mulyadi Purnawanto \\ Universitas Muhammadiyah Purwokerto \\ agoesmp@gmail.com
}

\begin{abstract}
Earthworms are invertebrates that have an important role in agro-ecosystems. Their burrow is the place where plant roots grow and develop and as well as the place where the water is stored. Earthworms are able to transform organic matters into inorganic matters that can be utilized by plants. Moreover, earthworms are also able to recover soil contaminated by heavy metals (soil bioremediation) by reducing the concentration of pollutants through the bioaccumulation mechanism of contaminants in their body
\end{abstract}

Keywords: earthworms, soil bioremediation, organic matter

\section{INTRODUCTION}

Earthworms are the most abundant soil invertebrates in temperate regions and are extremely important for soil formation [1]. Earthworms participate in nutrient cycling in terrestrial ecosystems and in the formation of soil profile from the physical, chemical and biological characteristics [2]. They improve the soil structure by increasing the macro porosity which affects aeration, water dynamics, organic and inorganic matter breakdown [3]-[4].

Different earthworm species have different effects on soil formation because of their different behavioral patterns. Epigeic earthworms live above the mineral soil, they rarely form burrows and prefer to eat the waste of plants. Endogeic species live below the surface, they build predominantly horizontal burrows. These species ingest large amounts of mineral soils and humus materials. Anecic earthworms vertically build permanent burrows deep into the mineral soil layer and come to the surface to eat on decomposed plant waste and other organic residues [5].

The breeding of earthworms on organic waste depends on external factors (abiotic and biotic) and the internal characteristics of species [6]. The best conditions for breeding and generating active earthworms, are on food which contain $60 \%$ cellulose and 10 to $20 \%$ protein. Earthworms do not tolerate spicy or acidic food waste such as: onion, garlic, or citrus fruit. Yet fats, bones, and animal dung have negative effects on the composting process [7].

Vermicompost (earthworm compost) is the final product of organic matters after being crushed by earthworms in a mesophilic composting process or known as vermicomposting. The red worm (Eiseniafetida) is widely considered as the best species at converting organic matter into compost, furthermore, it intensively eats and breeds quickly. Composting is a biochemical process that uses microorganisms to aerobic organic matter decomposition. In the vermicomposting method, microorganisms begin the process, but the red worm has the largest role in converting organic matter at the preliminary decomposition process (e.g. hydrolysis or fermentation). Composting by those organisms is effective in $15-25^{\circ} \mathrm{C}$, and with humidity between 60 $70 \%$. If the conditions are beyond the optimum scope, the effectiveness declines [8].

\section{METHOD}

This research is a literature study (library research). It collects data from scientific papers which have the same object of study with the purpose of research. Therefore, the techniques used in the data collection is literature data collection or library materials coherent with the objects of the research problems. After that, the data isedited, organized and finally analyzed descriptively.

\section{RESULT}

\section{The role of earthworms burrow}

The interactions between plant and the foraging behaviors of animal species impact those species population and community dynamics. In North American forests, invasions by European earthworms have led to substantial changes in plant community compositions. Changes in leaf waste have been identified as an indirect mechanism which leads to earthworms' impacts on plants. Whereas, the direct effect examination of earthworm burrowing on plant growth shows that earthworms (Lumbricusterrestris L.) affect plant root in foraging process. In a minirhizotron experiment, roots are more frequently found in burrows and soil cracks in the soil matrix [9].

Earthworms give indirect effects through the changes of roots environment or through interactions between organisms that affect root growth and production [10]. They, as the ecosystem machine, modify their environment and stimulate the soil bacteria abundance and activity through the production of their mucus. They produce hormones and substances that contain energy such as mucus that stimulates soil microorganisms. And, when it is activated, it can enhance plant vigor [11]. High geophagous earthworm populations are able to increase plant production due to their ameliorating effects on the physical and chemical properties of the soil (faster nutrient mineralization rate and water availability) [12].

The ability of earthworms to move and the ability of plant roots to grow, breaking through soil significantly, 
affect their capacity to absorb resources. The increase of soil compaction gradually decreases the earthworms' speed and ability of biological growth and movement in soil until a certain critical limit and movement is stopped. Before reaching this critical point, both earthworms and plant roots can work to break up soil, thus it will enhance the negative impacts of soil compaction and improve their own biological habitats. Earthworms construct large tunnel networks with length of 1 to $2 \mathrm{~m}$ for each one. These burrows involve large amounts of displaced soil that may exceed $100 \mathrm{~kg} \cdot \mathrm{m}^{-2}$ ground area per year. While the growth of plant roots contributesless to the formation of soil bio pores. Land mass associated with the process of plant root growth is approximately equal to $1 \mathrm{~kg} \mathrm{~m}^{-2}$ land area per year[13].

The arrangement of soil particles and pore spaces form the soil structure in various rangesof scales; and this has a function of interaction among soil water status and the larger activity of the soil biota such as plant roots or earthworms, and also the presence of organic matters and soil tillage in some agricultural systems [14]. The increase in infiltration rate related to earthworm burrows can decrease the soil erosion by $50 \%$ [15]. In the tropics, endogeic species increase soil porosity and water infiltration, thereby it reduces the runoff. Erosion rates exponentially decrease as a function of anecic earthworm biomass. Water storage can be different according to the earthworm species and climate conditions. The increase in bulk density by endogeic compacting species was associated with $7 \%$ decrease in water storage capacity of the soil, which could be detrimental to the plant growth in water-deficient conditions [16].

The higher soil water level and the decrease of clay content reduce the strain energy required in soil penetration. The pressure of earthworm or root will increase with the increase of root or earthworm diameter. The mechanical energy discharged per length increases in line with the increase of earthworm and plant root diameters, whereas mechanical energy per unit of displaced soil volume decreases with larger diameters. The estimated required energy for earthworm biopore networks are linked to the consumption of soil organic matter and suggest that earthworm populations are likely to consume a significant fraction of ecosystem net primary production to sustain their subterranean activities [17].

\section{The role of earthworms to degradation of organic matter}

Earthworms are heterotrophic organisms that involve in the degradation of organic matter and molecules, mainly produced by plants and other heterotrophic organisms. Earthworms accelerate the organic matter degradation by increasing the available surface area of organic matter through destruction process [18]. After digestion, some organic compounds are released into the environment as small organic compounds or mineral nutrients. These mineral nutrients, especially nitrogen $(\mathrm{N})$, are re-used by plants. Nitrogen mineralization increases because of earthworms, either directly through the release of $\mathrm{N}$ by their metabolic products (casts, urine and mucus, which contains $\mathrm{NH}_{4}{ }^{+}$, urea, and uric acid) and dead tissues; or indirectly through changes in soil physical properties and fragmentation of organic material, and also through interactions with other soil organisms[19]. Earthworms accelerate N mineralization from the organic matter, but the effect depends on the species and their interactions with other soil biota, soil characteristics and the location of the organic matter [20].

In laboratory experiments, it is[21]foundthat the epigeic earthworm, Eisenia veneta Rosa, accelerated the weathering of anorthite, biotite, smectite and kaolinite; smectite was transformed to illite and kaolinite reacted to produce a new mineral phase. Compared to mineral weathering, the role of earthworms in humus formation has been investigated more thoroughly. The darkening of soil mold is a slow process, which involves chemical reactions and especially microbial activity. This process, nevertheless, can be accelerated by earthworms that prepare the soil and litter mixtures composed of fragmented and macerated leaves and fine soil particles for microbial attack [22].

The use of earthworms in waste management has long been documented. The organic material will undergo a process conducted by earthworm to produce vermicomposting. Some epigeic earthworm species are often used as biological agents in the process of vermicomposting [23]. Vermicomposting contains active microorganisms and enzymes that can increase fertility of biochemically degraded soils. Therefore, the use of vermicomposting as the organic amendment material is a promising alternative, suitable and inexpensive technology to remediate the heavy metal contaminated sites [24].

\section{The role of earthworms to soil bioremediation}

Over the last few centuries the human activities for exploitation of natural resources have had a negative impact on the global balance of heavy metals and have resulted inthe increase of metal concentration in the soil's ecosystem [25]. Heavy metals have features such as bioaccumulation, toxicity, high chemical stability, low biodegradability, and high solubility in water, in which those features are causing a widespread pollution on the soil surface [26].

In the field of environmental risk assessment, the earthworms are considered as the major component of the soil, and an important bio-indicators to measure the environmental health and quality of the soil [27]-[28]. These organisms can accumulate high concentration of heavy metals in the body [29]. In recent years, earthworms have been used for the treatment of soil to remove the insecticide used in agriculture, heavy metals and petroleum pollutants out of the soil [29]. The use of earthworms on soil bioremediation is a biological method, so that the pollutant concentrations in the soil are reduced through bioaccumulation mechanisms in the body of the earthworms [30]. The most important applications of these organisms consist of the treatment 
in the waste management process acting as a biosorbent in soil detoxification and bioremediation out of heavy metals, persistent hydrocarbons and some organic pesticides.It also causes the population growth of the beneficial microorganisms in the soil and strengthen their enzyme activities as well as improve the soil quality and agricultural development [31].

Earthworms can be used as bio indicators of environmental damage to the toxicity of a chemical compound, because earthworms are able to accumulate the chemical compounds in the environment into their body [32]. Earthworms can also significantly reduce concentrations of heavy metals [32].

Chromium and Cadmium are two heavy metals existing in the soil. Cadmium is a metal causing kidney lesions, mutagenic, carcinogenic, and increase in blood pressure. Chromium is an essential element for humans and animalhealth, but in excessive amount, especially in the form $\mathrm{Cr}$ (VI), it will be harmful for health causing lung and colon cancers [33].

The use of earthworms to bio remediate the soils results in reducing the pollutants concentration through a bioaccumulation mechanism on the contaminants in the earthworm's body. There is a significant correlation between the reduction of chromium and cadmium metals in the soils and the accumulation of chromium and cadmium metals in the earthworms' body. The mortality of worms in the soil at a concentration of $0.08 \mathrm{mg} . \mathrm{g}-1$ of chromium increases, therefore using the worms for bioremediation is not recommended at such concentration of chromium but using the worms for the removal of cadmium at concentrations of $0.04 \mathrm{mg} . \mathrm{g}-1$ and $0.08 \mathrm{mg} . \mathrm{g}-1$ in the soil is recommended [34]. 20 and $40 \%$ of the earthworms could survive until day 30 in organic media contaminated with $\mathrm{Pb}$ and $\mathrm{Cd}$, respectively. $\mathrm{Pb}$ accumulated in the earthworms'body ranges from 0.03 to $211.42 \mathrm{mg} . \mathrm{kg}^{-1}$, while the $\mathrm{Cd}$ accumulated in the earthworm body ranges from 0.57 to $22.11 \mathrm{mg} \cdot \mathrm{kg}^{-1}$. The bioaccumulation factor for Pbis $46.98 \%$, while that of $\mathrm{Cd}$ is $53.83 \%$. The content of $\mathrm{Pb}$ in vermicomposting ranges from 0.04 to $19.41 \mathrm{mg} \cdot \mathrm{kg}^{-1}$, while that of $\mathrm{Cd}$ ranges from 0.01 to $1.58 \mathrm{mg} . \mathrm{kg}^{-1}$ [35]

Earthworms are in permanent contact with soil particles via their permeable skin and digestive tract and so that it is strongly affected by pollutants in the soil. Earthworms often live in very hostile environments with an abundant micro flora and therefore they have to own strong developmental defense mechanisms. These mechanisms have been described to be influenced by various types of organic and inorganic pollutants and also by the nanoparticles that reach the soil system. The lack of earthworms ability to protect themselves against pathogenic microorganisms causes the lower reproduction rates and increasing mortality[36].

\section{CONCLUSION}

Earthworms are well known for their abilities to improve soil structure, fertility, and agricultural production. Earthworms have an important role as a machine in many soils, in which they contribute to the complex processes of organic matter decomposition and affect aeration, water transport, and soil structure. Acute toxicity tests with earthworms are useful, but they are designed to identify very toxic chemicals that have immediate effects on earthworms and not to determine acceptable environmental concentrations. The use of earthworms as biological monitors to determine accumulations of pollutants in their tissues as an integrative estimate of the degrees of pollution is an attractive idea fraught with practical difficulties.

\section{REFERENCES}

[1] C. A. Edwards, Earthworms Ecology. 2004.

[2] M. D. Bartlett, M. J. I. Briones, R. Neilson, O. Schmidt, D. Spurgeon, and R. E. Creamer, "A critical review of current methods in earthworm ecology: From individuals to populations," Eur. J. Soil Biol., vol. 46, no. 2, pp. 67-73, 2010.

[3] B. Wen, Y. Liu, X. yu Hu, and X. quan Shan, "Effect of earthworms (Eisenia fetida) on the fractionation and bioavailability of rare earth elements in nine Chinese soils," Chemosphere, vol. 63, no. 7, pp. 1179-1186, 2006.

[4] E. Ruiz, J. Alonso-Azcárate, and L. Rodríguez, "Lumbricus terrestris L. Activity increases the availability of metals and their accumulation in maize and barley," Environ. Pollut., vol. 159, no. 3, pp. 722-728, 2011.

[5] J. Kostecka and J. Mroczek, "Modelling the Processes of Vermicomposting in an Ecological Box - Recognized Critical Points," no. 9, pp. 143156, 2011.

[6] Munroe Glenn, "Manual of On-Farm Vermicomposting and Vermiculture," Org. Agric. Cent. Canada, p. 56, 2007.

[7] S. Suthar, "Earthworm density, casting activities and its impact on canopy soil nutrient profile under different aboveground vegetations," Environmentalist, vol. 31, no. 3, pp. 227-236, 2011.

[8] E. K. Cameron, J. F. Cahill, and E. M. Bayne, "Root foraging influences plant growth responses to earthworm foraging," PLoS One, vol. 9, no. 9, 2014.

[9] P. Lavelle et al., Effect of earthworms on soil organic matter and nutrient dynamics at a landscape scale over decades. 2004.

[10] P. Lavelle, S. Barot, M. Blouin, T. Decaëns, J. J. Jimenez, and P. Jouquet, Ecosystem Engineers Plants to Protists, vol. 4. 2007.

[11] R. Kohler-milleret, C. Le Bayon, S. Tarnawski, P. Boivin, and J. Gobat, "Earthworm , mycorrhiza and root interactions : their effects on some chemical, physical and biological soil properties," pp. 81-83, 2010.

[12] W. D. Shuster, L. P. McDonald, D. A. McCartney, R. W. Parmelee, N. S. Studer, and B. R. Stinner, "Nitrogen source and earthworm abundance affected runoff volume and nutrient loss in a tilled- 
corn agroecosystem," Biology and Fertility of Soils, vol. 35, no. 5. pp. 320-327, 2002.

[13] M. Blouin, P. Lavelle, and D. Laffray, "Drought stress in rice (Oryza sativa L.) is enhanced in the presence of the compacting earthworm Millsonia anomala," Environ. Exp. Bot., vol. 60, no. 3, pp. 352-359, 2007.

[14] S. Ruiz, D. Or, and S. J. Schymanski, "Soil penetration by earthworms and plant roots Mechanical energetics of bioturbation of compacted soils," PLoS One, vol. 10, no. 6, pp. 1-27, 2015.

[15] J. Seeber, G. U. H. Seeber, R. Langel, S. Scheu, and E. Meyer, "The effect of macro-invertebrates and plant litter of different quality on the release of $\mathrm{N}$ from litter to plant on alpine pastureland," Biol. Fertil. Soils, vol. 44, no. 5, pp. 783-790, 2008.

[16] M. Eroglu S., Toprak S., Urgan O, MD, Ozge E. Onur, MD, Arzu Denizbasi, MD, Haldun Akoglu, MD, Cigdem Ozpolat, MD, Ebru Akoglu, Biology of earthworms, vol. 33. 2012.

[17] O. Butenschoen, S. Marhan, R. Langel, and S. Scheu, "Carbon and nitrogen mobilisation by earthworms of different functional groups as affected by soil sand content," Pedobiologia (Jena)., vol. 52, no. 4, pp. 263-272, 2009.

[18] D. Carpenter, M. E. Hodson, P. Eggleton, and C. Kirk, "Earthworm induced mineral weathering: Preliminary results," Eur. J. Soil Biol., vol. 43, no. SUPPL. 1, 2007.

[19] C. Edwards, Vermiculture Technology. 2011.

[20] A. A. Ansari, "Reclamation of sodic soils through vermitechnology," vol. 1, no. March, pp. 27-31, 2007.

[21] M. J. Fernández-Gómez, E. Romero, and R. Nogales, "Feasibility of vermicomposting for vegetable greenhouse waste recycling," Bioresour. Technol., vol. 101, no. 24, pp. 9654-9660, 2010.

[22] R. Kizilkaya, "The role of different organic wastes on zinc bioaccumulation by earthworm Lumbricus terrestris L. (Oligochaeta) in successive $\mathrm{Zn}$ added soil," Ecol. Eng., vol. 25, no. 4, pp. 322-331, 2005.

[23] B. H. Robinson, M. Leblanc, D. Petit, R. R. Brooks, J. H. Kirkman, and P. E. H. Gregg, "The potential of Thlaspi caerulescens for phytoremediation of contaminated soils," Plant Soil, vol. 203, no. 1, pp. 47-56, 1998.

[24] J. Nahmani, M. E. Hodson, S. Devin, and M. G. Vijver, "Uptake kinetics of metals by the earthworm Eisenia fetida exposed to fieldcontaminated soils," Environ. Pollut., vol. 157, no. 10, pp. 2622-2628, 2009.
[25] T. Sizmur and M. E. Hodson, "Do earthworms impact metal mobility and availability in soil? - A review," Environ. Pollut., vol. 157, no. 7, pp. 19811989, 2009.

[26] L. Li, Z. Xu, J. Wu, and G. Tian, "Bioaccumulation of heavy metals in the earthworm Eisenia fetida in relation to bioavailable metal concentrations in pig manure," Bioresour. Technol., vol. 101, no. 10, pp. 3430-3436, 2010.

[27] E. Schreck, F. Geret, L. Gontier, and M. Treilhou, "Neurotoxic effect and metabolic responses induced by a mixture of six pesticides on the earthworm Aporrectodea caliginosa nocturna," Chemosphere, vol. 71, no. 10, pp. 1832-1839, 2008.

[28] I. B. Slizovskiy and J. W. Kelsey, "Soil sterilization affects aging-related sequestration and bioavailability of $\mathrm{p}, \mathrm{p}^{\prime}$-DDE and anthracene to earthworms," Environ. Pollut., vol. 158, no. 10, pp. 3285-3289, 2010.

[29] S. Sharma, K. Pradhan, S. Satya, and P. Vasudevan, "Potentiality of Earthworms for Waste Management and in Other Uses - A Review," Am. J. Sci., vol. 1, no. 1, pp. 4-16, 2005.

[30] R. Peiravi, H. Alidadi, A. A. Dehghan, and M. Vahedian, "Heavy Metals Concentrations in Mashhad Drinking Water Network," Zahedan J. Res. Med. Sci., vol. 15, no. 9, pp. 74-76, 2013.

[31] E. Aseman-Bashiz, H. Asgharnia, H. Akbari, L. Iranshahi, and G. R. Mostafaii, "Bioremediation of the Soils Contaminated with Cadmium and Chromium, by the Earthworm Eisenia fetida," Anu. do Inst. Geociencias, vol. 37, no. 2, pp. 216-222, 2014.

[32] M. Arifin, W. H. Utomo, Y. Nur, and T. Wardiyati, "The potential of Lumbricus rubellus as a bioaccumulator of excess $\mathrm{Pb}$ and $\mathrm{Cd}$ in organic media," J. Degrad. Min. Lands Manag., vol. 2, no. 4, pp. 397-402, 2015.

[33] R. Roubalová, P. Procházková, J. Dvo, F. Škanta, and M. Bilej, "ISJ 12 : 203-213, 2015 - Invertebrate Survival Journal ( ISJ ) ISSN 1824-307X The role of earthworm defense mechanisms in ecotoxicity studies Abstract Earthworms are important soil organisms that affect the soil structure by influencing organic and inorg," pp. 203-213, 2015. 